\title{
Examination on Foreign Direct Investment in the Tourism Industry in Kerala
}

\author{
G. Kanagavalli, Haseena. K. P
}

\begin{abstract}
Foreign Direct Investment (FDI) means investment by a person or firm from one country to the business located in another country. In India the major sectors where foreign direct investments permitted are infrastructure, automotive, pharmaceuticals, service, railway, chemicals, textile and airlines. Kerala always looking for FDI in innovative tourism projects. The infrastructure developments in tourism destinations are very crucial in attracting tourists. State Govt. is expecting annual growth of $15 \%$ in foreign tourist's arrivals. They expect 3 million foreign tourists by 2021. To reach those expectations there is a need to promote Ayurveda, Backwaters, Adventure tourism and Medical tourism. In Kerala, the tourism industry covers $13 \%$ of the state GDP. The central govt. wants to attract 100 billion dollar Foreign Direct Investment in tourism sector and generate up to 100 million jobs. During the period of April 2000 to June 2018, FDI inflows in to the state reached 1.97 billion dollar. South Korean Govt. has shown interest in investing in Kerala in electronic hardware manufacturing, knowledge industry, basic infrastructure development, pot development and shipbuilding. Elements of tourism industry include accommodation, tourist's sales, attractions, transportation, amenities etc. This study attempts to analyze the FDI in this various elements of tourism industry in Kerala. Secondary data are to be used for the study and tables and diagrams are used for presentation of the data.
\end{abstract}

Keywords : Foreign Direct Investment, Tourism industry..

\section{INTRODUCTION}

FDI means investment made by a firm or individual to another country in the form of controlling ownership. It means the investment in securities like bonds and stocks. FDI can be made in different ways such as incorporating wholly owned subsidiary, by acquiring shares, through mergers or acquisitions or by participating in joint venture.FDI investment can be made horizontal, vertical or conglomerate. FDI always helps to improve the economic growth of every country through accumulation of capital. In India, mainly FDI are made in sectors such as services, computer hardware and software, telecommunications, trading and constructions. Service sector includes banks, insurance companies, credit information companies etc. Through FDI, countries get infrastructure, energy, transportation and water which helps for increasing wages and job opportunities. In the 2019 Budget, the central finance minister , Nirmala sitaraman, announced that India will ease foreign direct

Revised Manuscript Received on October 15, 2019.

* Correspondence Author

Dr. G.Kanagavalli, Assistant Professor, Department of Commerce, Alagappa University, Karaikudi, India.

Haseena.K.P, Research scholar, Department of Commerce, Alagappa University, Karaikudi, India investment restrictions in single brand retail and will open up FDI in aviation, insurance, media and animation sectors. The tourism and hospitality sector is the included in the top 15 sectors in India which attracts highest foreign direct investment.

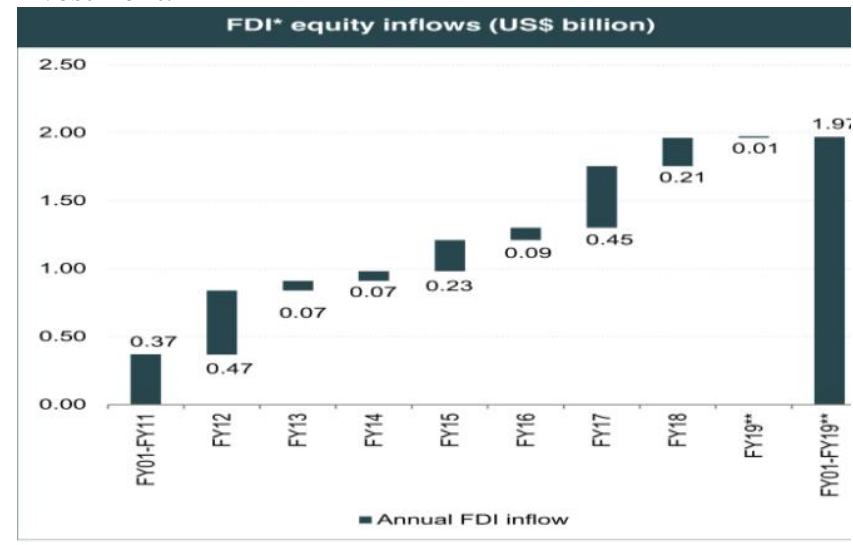

\section{Tourism in Kerala}

Kerala, situated in the tropical coast of Southwestern India, is one of the famous tourist destinations in the country. Kerala is called as the God's own country. The state was famous for high mountains, ayurvedic treatments, deep cut valleys, evergreen rain forests, backwaters and food items. The tourism industry is flourishing because of the ecological wonders in Kerala, the classical art forms, colorful festivals in Kerala, delectable fresh local cousine temples and archeological sites along with the infrastructure. Here the tourist activities are regulated by a public sector undertaking known as Kerala Tourist Development Council (KTDC) through its branches in all the districts .KTDC has more than 40 properties including 5 star resorts to budget accommodations which is managed in five brands under hotel category and the two in non hotel hospitality category. Tourism in Kerala is flourishing. There are different concepts of Tourism

a) Heritage and cultural tourism : According to the National trust for Historic preservation in the united states defines heritage tourism as travelling to experience the places, artefacts and activities that authentically represent the stories of the people in the past.

b) Eco tourism: Tourism in the natural environment to observe and support wildlife is called as eco tourism.

c) Hill station tourism: tourism at a place situated in higher elevation than nearby plain or valley. 


\section{Examination on Foreign Direct Investment in the Tourism Industry in Kerala}

d) Forest and wildlife tourism: tourism in the area, which is undomesticated, mainly in wildlife.

e) Backwater tourism: Tourism in backwaters, which is a part of rivers.

f) Beach tourism: travel for recreation, leisure and entertainment to beaches is called beach tourism.

g) Ayurvedic tourism: tourism which gives health care by use of ayurvedic treatments.

\section{Components of Tourism Industry}

Tourism industry means all those activities, which provide goods or services to business, pleasure and leisure activities away from home environment. It is important to identify the components of tourism industry in Kerala to analyze the extend of FDI in each area. Mainly the success of tourism industry depends on following components.

- Destinations and attractions

- Transportation

- Lodging and catering

- Intermediaries

- Information and guiding

The developing countries can carry out tourism easily through FDI. Now tourism became a most important source for increasing the GDP of a country, helps for generating employment opportunities and promotes foreign exchange.

\section{OBJECTIVES OF THE STUDY}

This study, 'Foreign Direct Investment in the tourism industry in Kerala' is conducted with the following objectives

- To identify the different components of tourism industry in Kerala

- To understand the various components of tourism industry where FDI is made.

- To understand the restrictions imposed on FDI on different sectors of tourism industry

- $\quad$ To analyze the growth of tourism through FDI

\section{METHODOLOGY OF THE STUDY}

The study mainly focused on secondary data. Data collected from Books, Magazines, Journals and official website of Government. Diagrams are to be used for the presentation of the data.

\section{FDI in different components of Tourism Industry}

As cited earlier, FDI in tourism industry can be analyzed with the help of various components of the industry.

\section{a) Destinations and Attractions.}

Destination means a place which has an attraction and which helps for earning money. Attraction means the ability of a place to attract and retain the visitors. Therefore, investment must be made to retain and protect the attractiveness some destinations. In Kerala, the main destinations for tourism are Munnar, Alappuzha, Kochi, Kovalam, Kumarakom, Thruvananthapuram, Wayanad, Ernakulam, Kozhikode, Vagamon, Athirappalli, Vebanad, Kannur fort, Ponmudi, Bekal, Chinnar, Wildlife Sanctuary, Kumily, devikulam, Silent valley, Guruvayoor, Thenmala, Gavi, Kuttanad etc. The union Govt. now allotted Rupees twenty million foe six important projects in Kerala. For Yathi nivas at Mannarkkad
7.5 million, Kumarakom ayurvedic health centre 2.5 million , Ayurvedic health centre at Bolgatty 2.5 million, Thekkady 2.5 million and Vythiri 2.5 million.

Under state Budget 2018-19 6.18 million dollar is allocated for tourist institutions and Muziris Heritage project. Also 12.67 million dollar is allocated for tourism marketing and 4.05 million dollar for KTDC, Kerala Tourism infrastructure, Bekal resort Development Corporation DTPC etc.

\section{b) Transportation}

Transportation is an inevitable part of tourism industry. Transportation helps to link different destinations, people, goods, and services. We can find different modes of transportation in tourism like air water, and road. In Kerala, transportation is not a big problem. There are private as well as public transport systems. In sea transport system there was a growth during the period 2000 to 2017. In 2014 FDI in Transport industry was 20.49 million Dollars and it is 735.06 million Dollar in 2017. The highest share of FDI in the sea transport sector is in 2016-17 year, which is $1.69 \%$.

Several multi nationals bade investments in the development of highways and various international companies made investments in transport industry. In the road sector $100 \%$ FDI is permitted. In 2018. Government of India allowed foreign airlines to invest in Air India up to $49 \%$ with govt. approval. The investment cannot exceed $49 \%$ diectly or indirectly.

\section{c) Lodging and Catering:}

The hotel and catering industry provides accommodation and food to the tourists. This industry consists of hotels, restaurants and rest houses. It is a part of hospitality industry. Hotel industry consists of hotels, motels, guest houses, inn with accommodations, highway rest areas, youth hostels, health resort hotels and campgrounds. Catering industry includes restaurants, café, bar, dancing clubs, spa restaurant, high way restaurants, factory canteens, social catering, and mobile catering. Accommodation is one of the basic needs for tourism industry. Majority of the tourist destinations provide a home to the tourist away from their home. Now the hotels are focusing to provide extra services to customers to attract and retain them.

In Kerala, based on the services provided by them, hotels are classified in to 5 star hotels, 4 star hotels, 3 star hotels, 2 star hotels and 1 star hotel. And there are unapproved hotels also are there.

The amount of FDI in hotel and tourism industry in 2000 was 13.2 million dollar and it was increased to 71.78 million dollar in 2006. It further increased to 308.05 million dollar in 2010-11 and in 2016-17 periods it was 916.13 million dollars. The highest annual growth in FDI in Hotel and tourism recorded in the year 2012-13. During the period of 2000-2019, the hotel and tourism industry attracted 12.35 billion dollars of FDI. Government has given permission for $100 \%$ FDI in the construction and development projects including hotels and resorts, recreational facilities and regional level infrastructure developments. 


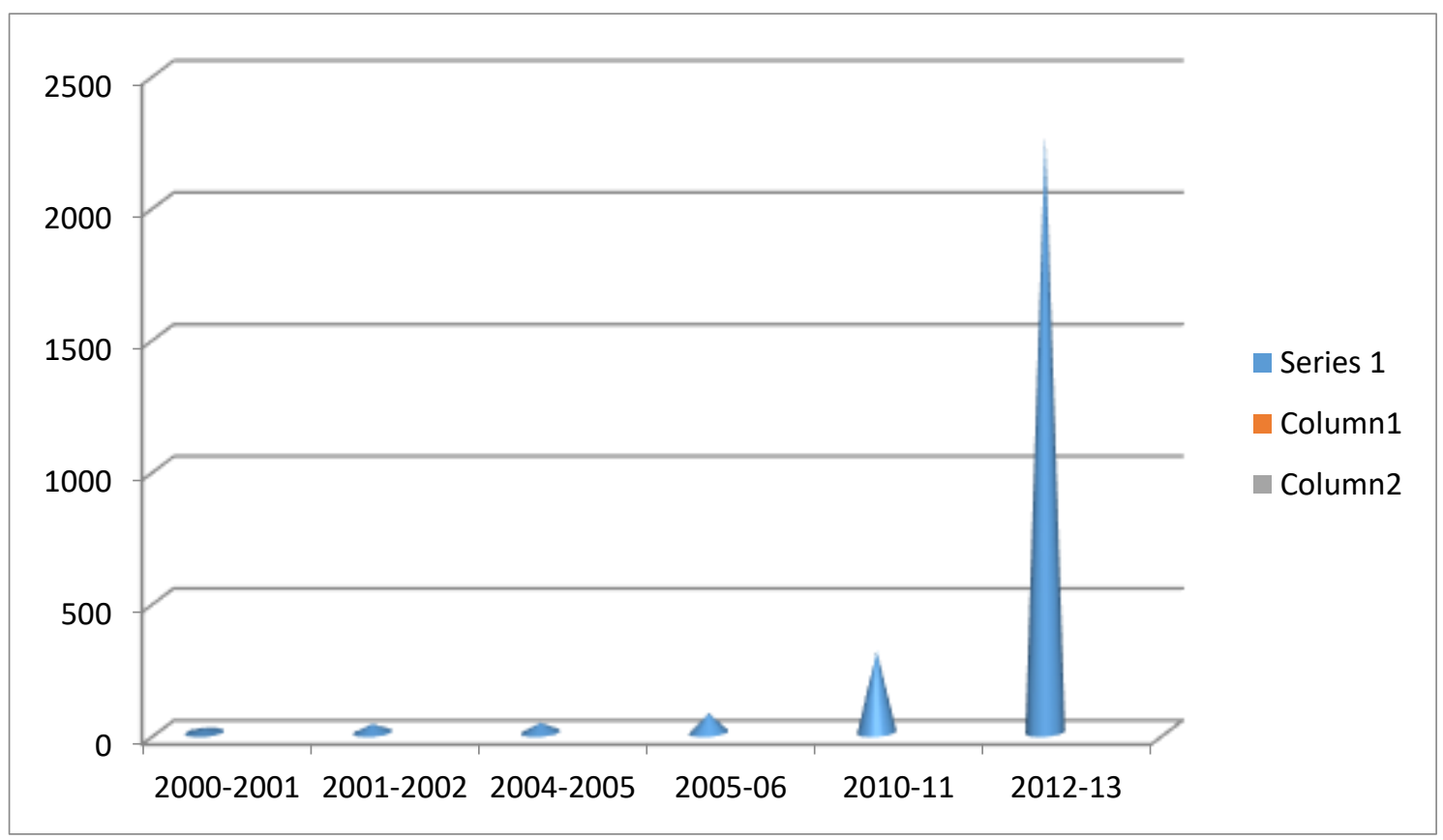

Figure 1: FDI in Hotel and Tourism Industry

During the period of 2000-2019, the hotel and tourism industry attracted 12.35 billion dollars of FDI. Government has given permission for $100 \%$ FDI in the construction and development projects including hotels and resorts, recreational facilities and regional level infrastructure developments.

\section{d) Intermediaries}

Intermediaries, otherwise known as travel agent or tour operators are the persons who provide guidance and assistance to the tourists. They may be private agencies or public service providers. They helps to co-ordinate the various components of tourism industry to the tourists. They explain about the tourist destinations, makes arrangement for transportation, accommodation and provides information and guiding. The tour operators also provide experienced guides to follow tourists. In the public sector, Kerala Tourism Development Council controls and manages the tourism related activities.

\section{e) Information and guiding}

Guiding and information sharing are important in tourism industry. It is the guides of tour operators provides information related to different destinations, routes, modes of transportation, costs, benefits, features and importance of different places. They also explain about the culture, importance, values and peculiarities of tourist destinations. There are different tourist information centres in destinations that provide wide range of brochures, books and maps to help the visitors.KTDC also created promotional movies of Kerala, panoramic 360 degree videos, e- brochures for promoting Malabar tourism, listing of accommodation list and list of tour operators, online booking system for tourists, online platform creation for village life experience package booking, responsible tourism network, tourism resource mapping etc.

\section{FINDING AND RESULTS}

This study proves that for the development of tourism industry in every state and in every country. Foreign Direct Investment plays a significant role. Since tourism is a crucial sector in an economy, which provides income, infrastructure development, employment generation, preservation of nature and promotion of economic development, the Govt. gave permission for FDI in tourism industry too. The promotion of tourism industry in a state consists of the developments in the accommodation, transportation, infrastructure, guidance, entertainment capacity, in a place. Kerala also receiving FDI, which was invested mainly in construction works and transportation in the tourism industry. The main reason is that the infrastructure developments in a destination are the most important factor that affects the success of tourism industry. Since hotel and tourism is one of the booming sectors in the Indian economy, it is much contributing to the gross domestic product of a country. Therefore Kerala, the god's own country also concentrating on such area. In India, $100 \%$ FDI is permitted in though various approvals. In Kerala, now we can watch the differences that happened after the flow of funds and capital from foreign countries. Through we can promote the service sector in Kerala.

\section{CONCLUSION}

Eventhough the folds happened in the years 2018and 2019 affected the tourism industry in Kerala to a certain extend measures were immediately taking to cover that. Since all the components of s system are important for the proper working of a system, the tourism industry should get FDI in each component and should help to promote the economic development the state and thereby in the country. 


\section{Examination on Foreign Direct Investment in the Tourism Industry in Kerala}

\section{REFERENCES}

1. Community.data.govt.in

2. Indiatourism stat

3. Economic times -05 july 2019

4. Directorate of economics and statistics of Kerala economic survey

5. Department of industrial policy and promotion, govt. of kerala

6. www.investindia.com

7. www.businessstandard.com

8. Business.mapsofindia.com 